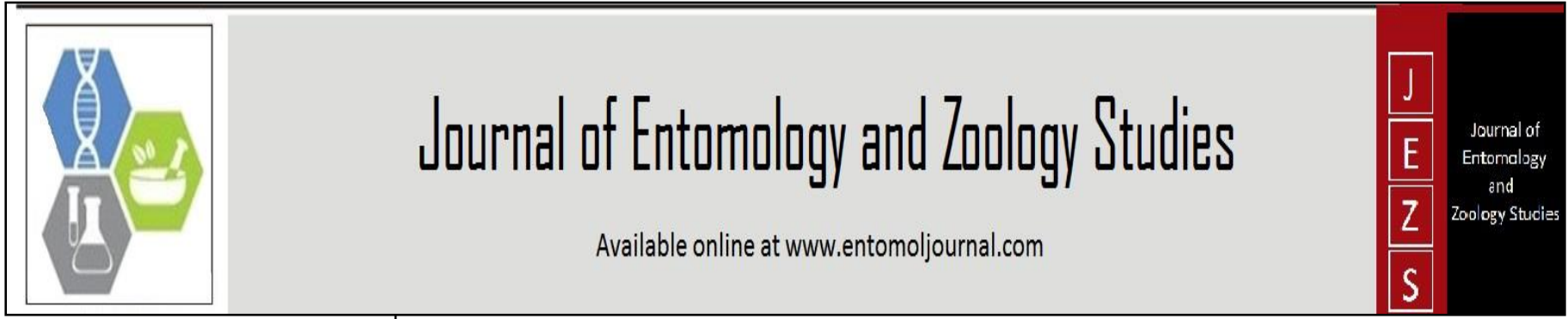

E-ISSN: 2320-7078

P-ISSN: 2349-6800

www.entomoljournal.com

JEZS 2021; 9(1): 1815-1820

(C) $2021 \mathrm{JEZS}$

Received: 04-11-2020

Accepted: 06-12-2020

S Chandrakar

Health and Forensic Centre, Dau Shri Kamdhen

Vishwavidyalaya, Durg, Chhattisgarh, India

JK Khutey

Wildlife Health and Forensic Centre, Dau Shri Vasudev Chandrakar Kamdhen

Vishwavidyalaya, Durg, Chhattisgarh, India

S Roy

Wildlife Health and Forensic Centre, Dau Shri Vasudev Chandrakar Kamdhenu

Vhwavidyalaya, Durg-491001, Chhattisgarh, India

J Singh

Wildlife Health and Forensic Centre, Dau Shri Vasudev Chandrakar Kamdhenu

Vasudev Chandrakar Kamdhenu
Vishwavidyalaya, Durg, Chhattisgarh, India

SL Ali

Department of Veterinary Medicine, College of Veterinary Science \& A.H., Dau Shri Vasudev Chandrakar Kamdhenu Vishwavidyalaya, Durg, Chhattisgarh, India

M Roy

Department of Veterinary Physiology \&

Biochemistry, College of Veterinary Science

A.H., Dau Shri Vasudev Chandrakar

Kamdhenu Vishwavidyalaya, Durg,

Chhattisgarh, India

NE Gade

Department of Veterinary Physiology \&

Biochemistry, College of Veterinary Science

A.H., Dau Shri Vasudev Chandrakar

Kamdhenu Vishwavidyalaya, Durg.

Chhattisgarh, India

N. Jangade

Department of Animal Breeding and Genetics, National Dairy Research Institute, Karnal, Haryana, India

Smita

Department of Veterinary Public Health,

College of Veterinary Science \& A.H., Dau Shr Vasudev Chandrakar Kamdhenu

Vishwavidyalaya, Durg, Chhattisgarh

D Markandey

Department of Veterinary Medicine, College of Veterinary Science \& A.H., Dau Shri Vasudev Chandrakar Kamdhenu Vishwavidyalay

Durg, Chhattisgarh, India

S Meshran

Department of Veterinary Medicine, College of Veterinary Science \& A.H., Dau Shri Vasudev Chandrakar Kamdhenu Vishwavidyalaya,

Durg-491001, Chhattisgarh, India

RS Kashyap

Department of Veterinary Medicine, College of Veterinary Science \& A.H., Dau Shri Vasudev Chandrakar Kamdhenu Vishwavidyalaya

Durg, Chhattisgarh, India

B Mishra

Wildlife Health and Forensic Centre, Dau Shri Vasudev Chandrakar Kamdhenu

Vishwavidyalaya, Durg Chhattisgarh, India

\section{Correlation of macro-micro mineral status with parasitic infection in captive wild carnivores of Chhattisgarh, India}

\author{
S Chandrakar, JK Khutey, S Roy, J Singh, SL Ali, M Roy, NE Gade, \\ Smita, N Jangade, D Markandey, S Meshram, RS Kashyap and B Mishra
}

DOI: https://doi.org/10.22271/j.ento.2021.v9.i1z.8667

\begin{abstract}
The aim of this study was to correlate macro-micro mineral status with gastrointestinal parasitic (GIP) infection in wild carnivores kept in captivity in 03 Zoos of Chhattisgarh. A total of 278 faecal samples of captive wild carnivores were collected during summer and pre-monsoon and soil, water and meat samples ( $\mathrm{n}=6$ each) were also collected from 03 zoos to estimate the macro-micro mineral level. Faecal samples were examined by direct examination, floatation, sedimentation and McMaster method. Soil, water and meat samples were subjected to acid digestion followed by estimation using Atomic Absorption Spectrophotometer. The zoo wise prevalence of GIP reported to be $34.78 \%, 15.47 \%$ and $29.05 \%$ in MBZ, NVZ\&S, and KPZ respectively. The macro and micro mineral level in soil, water and meat samples of 03 zoos was observed to be lower than the normal values. It was observed that macromicro mineral level in soil, water and meat samples had significant effect on prevalence of GIP in captive carnivores under study.
\end{abstract}

Keywords: macro-micro minerals, captive wild carnivores, zoos, EPG

\section{Introduction}

The most important hosts for a large number of parasites are canids in case of wild carnivores (Joshi, 1991) ${ }^{[8]}$ and their survival can be affected directly through pathological effects and indirectly by reducing the host's immunity (Thiangtum et al., 2006) ${ }^{[21]}$. Wild animals may possess resistance against parasitism naturally or may have created balanced system with their parasites in natural environment but any deviation in the environment or living conditions from free-living to captivity influences the animals' ecology and might increase its sensitivity for parasitism (Maske et al., 1990; Chakraborty et al., 1994) ${ }^{[10,4]}$.

Captivity creates an unnatural system for wildlife which disrupts the balance between parasite and host and creates a stressful environment due to which animals become diseased or can even die from parasitic loads that they would have survived under natural conditions (VanWyk and Boomker, 2011) ${ }^{[22]}$. Additional problem in modern era of Veterinary medicine is that even though a variety of anthelmintic drugs are commercially available for treatment of the endoparasitic infection but still it is practically difficult to completely eliminate the infective stages of the parasites from the environment as well as the host. For these reasons, it is considered very important to conduct preventive measures regularly, to control the presence of parasite infections in animals and to undertake the adequate therapy when it is required (Sahoo et al., 2009) ${ }^{[14]}$.

Application of existing knowledge of disease control and prevention would significantly reduce economic losses due to gastro-intestinal helminthosis (Barmon et al., 2014) ${ }^{[2]}$. Minerals play important role affecting susceptibility of animal's parasitic burden and have direct anthelmintic affect by influencing host metabolism and modulate immunity of the animal. According to recent evidences, the malnutrition supported prolonged nematode survival is developed by the alterations of immune functions (Fekete and Kellems, 2007) ${ }^{[7]}$. Information on parasitic infections of wild animals is meager due to paucity of systematic investigations in our country (Varadharajan and Kandasamy, 2000) ${ }^{[23]}$. Scare reprots exist wherein an attempt to correlate endoparasitic infection in wild animal species with macro-micro minerals 
concentration in soil, plant and water has been carried out (Mishra, 2017) ${ }^{[12]}$. Hence, present study was envisaged with an attempt of find out any correlation between GIP in captive wild carnivores in relation to macro-micro mineral content of soil water and meat.

\section{Materials and Methods \\ Study area}

The present study was carried out in 03 different zoos of Chhattisgarh Viz. Maitri Bagh Zoo (MBZ), Bhilai; Nandanvan Zoo and Safari (NVZ\&S), Raipur and Kanan Pendari Zoo (KPZ), Bilaspur.

\section{Faecal sample collection}

A total number of 278 faecal sample of captive wild carnivores were collected during summer and pre-monsoon $(n=139$ each) from 03 zoos of Chhattisgarh. A total of 278 faecal samples were collected from 03 different zoos, out of which 46 samples were collected from MBZ, 84 faecal samples from NVZ\&S and 148 samples from KPZ. Fresh faecal samples were collected from the captive enclosure in clean, dry interlocked polythene bags. The samples were labeled with various details like species, age, sex and enclosure number for easy identification of the samples during laboratory investigation (Khutey et al., 2020) ${ }^{[9]}$.

Faecal samples were collected from different species of wild carnivores Viz. Asciatic lion (Panthera leo persica) $(\mathrm{n}=24)$, Royal Bengal Tiger (Panthera tigris tigris) $(\mathrm{n}=35)$, Leopard (Panthera pardus) $(\mathrm{n}=21)$, Jackal (Canis aureus) $(\mathrm{n}=24)$, Hyaena (Hyaena hyaena) $(\mathrm{n}=11)$, Fox (Vulpes bengalensis) $(\mathrm{n}=19)$ and Jungle Cat (Felis chaus) $(\mathrm{n}=05)$ during both season (Chandrakar et al., 2020) ${ }^{[5]}$.

\section{Soil sample collection}

Soil samples ( $\mathrm{n}=6$ from each $\mathrm{zoo}$ ) were collected from different areas of enclosure of 03 zoos for the estimation of macro and micro minerals. Soil surface was dug to about 15 $\mathrm{cm}$ depth in the ' $\mathrm{V}$ ' shape and the sides of the dugged area were scooped for sample collection. About 100 grams of soil sample was stored in clean interlocked polythene bags and were labeled accordingly (Mishra, 2017) ${ }^{[12]}$.

\section{Water sample collection}

Water samples were collected in polypropylene bottle of $100 \mathrm{ml}$ capacity, from the enclosures inside different zoos.

\section{Meat sample collection}

The meat samples were collected from the different zoos in a clean, dry and individually labeled plastic container in ice box.

\section{Faecal sample examination}

All faecal samples were subjected to routine corproscopical examination comprising of floatation and sedimentation technique followed by EPG count by MC Mater method as per routine protocol (Skerman and Hillard, 1966; Soulsby, 1982) ${ }^{[18,19]}$.

\section{Macro-micro mineral estimation \\ Mineral estimation of soil samples}

The collected soil samples were dried in shade under fan at room temperature for 48 hours and sieved through a $2 \mathrm{~mm}$ sieve to remove debris, pebbles, stones etc. About 1 gram of dried and ground soil sample was taken into a $250 \mathrm{ml}$ conical flask and subjected to acid digestion for $12 \mathrm{hrs}$. Then it was placed into block digester and heated at $125^{\circ} \mathrm{C}$ for 5 hours. The digested analyte was washed with distilled water making a volume of $50 \mathrm{ml}$ in a volumetric flask. The solution was analyzed for estimation minerals Viz. calcium, phosphorus, magnesium, iron, selenium, zinc and copper were estimated using Automic Absorption Spectrophotometer (Piper, 1942) [13].

\section{Mineral estimation of water samples}

Water sample was filtered through a $0.45 \mathrm{~mm}$ filter paper and then acidified by $1 \mathrm{ml}$ of concentrated $\mathrm{HNO}_{3}$ and the collected samples were stored in a dark place at room temperature until further analysis. The stored water samples were analyzed for macro and micro minerals Viz. calcium, phosphorus, magnesium, iron, selenium, zinc and copper by Atomic Absorption Spectrophotometer (APHA, 1998) ${ }^{[1]}$.

\section{Mineral estimation of meat samples}

Meat samples for mineral analysis were digested with 1:4 v/v mixture of perchloric acid (60 percent) and nitric acid (70 percent). The dilution was made with deionized water. Macro and micro nutrient elements Viz. calcium, phosphorus, magnesium, iron, selenium, zinc and copper were determined by using Atomic Absorption Spectrophotometer (Siddiqi et al., 1994) ${ }^{[15]}$.

\section{Results and Discussion \\ Zoo wise prevalence of GIP}

The zoo wise prevalence in our study was reported to be $34.78 \%$ (16/46), $15.47 \%$ (13/84) and $29.05 \%$ (43/148) in MBZ, NVZ\&S, and KPZ respectively. Comparison between different zoos reveled that significantly $(\mathrm{p}<0.05)$ higher prevalence of gastrointestinal nematodiasis in captive wild animals of MBZ as compared to KPZ and NVZ\&S.

Thawait et al. (2014) ${ }^{[20]}$ have also reported prevalence of helminthic infection in carnivores to be $28.33 \%$ in KPZ which is nearly similar to our findings. However, in same study, much higher prevalence $(45.2 \%)$ of helminthic infection was reported in captive carnivores of Nandanvan Zoo, Raipur.

\section{Mineral level of soil samples}

The macro and micro mineral content of soil samples collected from 03 different zoos is presented in table no. 1 .

The findings of our study revealed that calcium content of soil in MBZ, Bhilai was significantly $(\mathrm{p}<0.05)$ lower in summer and pre-monsoon season as compared to NVZ\&S, Raipur and KPZ, Bilaspur. The findings of our study are in concordance with those reported by Mishra (2017) ${ }^{[12]}$ who has reported mean calcium level in soil samples to be 1127.26 \pm 1.03 , $1130.43 \pm 0.87$ and $1126.59 \pm 1.27 \mathrm{mg} / \mathrm{kg}$ in winter, summer and rainy season respectively However, the calcium level in soil samples of our study is above the critical value of 71 $\mathrm{mg} / \mathrm{kg}$ as outlined by McDowell et al., (1984) ${ }^{[11]}$.

The level of phosphorus content of soil in MBZ, Bhilai was significantly $(\mathrm{p}<0.05)$ lower in summer and pre-monsoon season as compared to NVZ\&S, Raipur and KPZ, Bilaspur. The phosphorus level in soil samples collected from plain regions of Chhattisgarh has been reported to be $0.018 \mathrm{mg} \%$ (Singh et al., 2018) ${ }^{[17]}$ which is similar to the values obtained in our study.

The concentration of magnesium content of soil in MBZ, Bhilai was significantly $(\mathrm{p}<0.05)$ lower in summer and premonsoon season as compared to NVZ\&S, Raipur and KPZ, 
Bilaspur. The mean magnesium level in soil samples of our study are similar to those documented by Mishra (2017) ${ }^{[12]}$ where magnesium level in soil was reported to be $249.12 \pm$ $0.11,250.79 \pm 0.22$ and $248.79 \pm 0.22 \mathrm{mg} / \mathrm{kg}$ in winter, summer and rainy season respectively. Contrastingly higher values of magnesium content in soil samples during our study have been observed as compared to the critical value of $9.1 \mathrm{mg} / \mathrm{kg}$ (McDowell et al., 1984) ${ }^{[11]}$.

The findings of our study revealed that copper content of soil in MBZ, Bhilai was significantly $(\mathrm{p}<0.05)$ lower in summer and pre-monsoon season as compared to NVZ\&S, Raipur and KPZ, Bilaspur. The mean copper level in soil samples in our study are in congruity with those stated by Mishra (2017) ${ }^{[12]}$ wherein the mean values were reported to be $1.38 \pm 0.07$, $1.32 \pm 0.03$ and $1.37 \pm 0.09 \mathrm{mg} / \mathrm{kg}$ in winter, summer and rainy season respectively. However, the copper content in soil is above the critical value of $1 \mathrm{mg} / \mathrm{kg}$ for soil of subtropics and tropics (McDowell et al., 1984) ${ }^{[11]}$.

The concentration of iron content of soil in MBZ, Bhilai was significantly $(\mathrm{p}<0.05)$ lower in summer and pre-monsoon season as compared to NVZ\&S, Raipur and KPZ, Bilaspur. The mean iron level in soil samples of our study are in close proximity to those stated by Mishra (2017) ${ }^{[12]}$ wherein iron content of soil samples was reported to be $42.17 \pm 0.86$, $38.83 \pm 2.02$ and $40.5 \pm 1.61 \mathrm{mg} / \mathrm{kg}$ in winter, summer and rainy season respectively. However, the iron content in soil samples of our study is much higher than the critical value of 20 $\mathrm{mg} / \mathrm{kg}$ as reported by McDowell et al. (1984) ${ }^{[11]}$.

The level of zinc content in soil samples of MBZ, Bhilai was significantly $(p<0.05)$ lower in summer and pre-monsoon season as compared to NVZ\&S, Raipur and KPZ, Bilaspur. The values of zinc in soil samples during our study are almost similar to those stated by Mishra (2017) ${ }^{[12]}$ where zinc level in soil was reported to be $1.45 \pm 0.19,1.26 \pm 0.19$ and $1.42 \pm 0.2$ $\mathrm{mg} / \mathrm{kg}$ in winter, summer and rainy season respectively. However, the zinc content in soil samples of our study is little below the critical value of $1.5 \mathrm{mg} / \mathrm{kg}$ as reported by McDowell et al. (1984) ${ }^{[11]}$.

The concentration of selenium content in soil samples of all zoos were non-significantly $(p>0.05)$ different in summer and pre-monsoon season. A similar kind of selenium level in soil samples has been reported as $0.01 \pm 0.01,0.01 \pm 0.01$ and $0.01 \pm 0.01 \mathrm{mg} / \mathrm{kg}$ in winter, summer and rainy season respectively (Mishra, 2017) ${ }^{[12]}$. Similarly, the selenium content in soil is in close proximity to the critical value of $0.01 \mathrm{mg} / \mathrm{kg}$ as reported for soil of subtropics and tropical region (McDowell et al., 1984) ${ }^{[11]}$.

\section{Mineral level of water samples}

The macro and micro mineral content of water samples collected from 03 different zoos is presented in table no. 2 .

The level of calcium content in water samples of MBZ, Bhilai was significantly $(\mathrm{p}<0.05)$ lower in summer and pre-monsoon season as compared to NVZ\&S, Raipur and KPZ, Bilaspur. The mean calcium level in water samples of our study are similar to those stated by Mishra (2017) ${ }^{[12]}$ wherein calcium level in water was reported to be $41.54 \pm 0.35,42.03 \pm 0.06$ and $40.65 \pm 0.26 \mathrm{ppm}$ in winter, summer and rainy season respectively. The calcium content of water samples in our study is within the permissible limit of WHO (2002) $)^{[24]}$ guidelines (75 ppm).

The phosphorus content in water samples of MBZ, Bhilai was significantly $(\mathrm{p}<0.05)$ lower in summer and pre-monsoon season as compared to NVZ\&S, Raipur and KPZ, Bilaspur.
Almost similar value of mean phosphorus level $(0.103 \pm 0.009$ ppm) in water samples has been reported by Davis (2017) ${ }^{[6]}$.

The level of magnesium content in water samples of MBZ, Bhilai was significantly $(\mathrm{p}<0.05)$ lower in pre-monsoon season as compared to NVZ\&S, Raipur and KPZ, Bilaspur. The mean magnesium level in water samples of our study are similar to those stated by Mishra (2017) ${ }^{[12]}$ where magnesium level in water was reported to be $1.5 \pm 0.19,1.51 \pm 0.01$ and $1.41 \pm 0.03 \mathrm{ppm}$ in winter, summer and rainy season respectively. The magnesium content of water samples in our study is within the permissible limit (50 ppm) of WHO (2002) ${ }^{[24]}$ guidelines.

The copper content in water samples of MBZ, Bhilai was significantly $(\mathrm{p}<0.05)$ lower in summer season as compared to NVZ\&S, Raipur and KPZ, Bilaspur. The mean copper level in water samples of our study are in concordance with those stated by Mishra (2017) ${ }^{[12]}$ where copper level in water was reported to be $0.3 \pm 0.01,0.31 \pm 0.01$ and $0.3 \pm 0.01 \mathrm{ppm}$ in winter, summer and rainy season respectively. However, the copper content in water samples of our study is much higher than the permissible limit of $0.05 \mathrm{ppm}$ as stated by WHO (2002) ${ }^{[24]}$ guidelines.

The level of iron content in water samples of MBZ, Bhilai was significantly $(\mathrm{p}<0.05)$ higher in pre-monsoon season as compared to KPZ, Bilaspur. The mean iron level in water samples of our study are similar to those stated by Mishra (2017) ${ }^{[12]}$ where iron level in water was reported to be $1.51 \pm 0.01,1.52 \pm 0.01$ and $1.5 \pm 0.01 \mathrm{ppm}$ in winter, summer and rainy season respectively. The iron content in water samples of our study exceeds the permissible limit $(0.3 \mathrm{ppm})$ of WHO (2003) ${ }^{[24]}$ guidelines.

The zinc content in water samples of MBZ, Bhilai was significantly $(\mathrm{p}<0.05)$ lower in summer season as compared to NVZ\&S, Raipur and KPZ, Bilaspur. The mean zinc level in water samples of our study are in concordance with those stated by Mishra (2017) ${ }^{[12]}$ where zinc level in water was reported to be $2.9 \pm 0.41,3.18 \pm 0.15$ and $2.3 \pm 0.47 \mathrm{ppm}$ in winter, summer and rainy season respectively. The zinc content in water samples of 03 different zoos is within the permissible limit (5 ppm) as per standards of WHO (2002) ${ }^{[24]}$. The level of selenium content in water samples in 03 different zoos under study was non-significantly $(p>0.05)$ different from each other. However, the mean selenium level in water samples of our study are similar to those stated by Mishra (2017) where selenium level in water was reported to be 0.01 $\pm 0.00,0.01 \pm 0.00$ and $0.01 \pm 0.00 \mathrm{ppm}$ in winter, summer and rainy season respectively. The selenium content in water samples of our study is within the permissible limit of WHO (2002) ${ }^{[24]}$ guidelines (0.01 ppm).

\section{Mineral level of meat samples}

The macro and micro mineral content of meat samples collected from 03 different zoos is presented in table no. 3 .

The calcium content in meat samples of MBZ, Bhilai was significantly $(\mathrm{p}<0.05)$ lower in summer and pre-monsoon season as compared to NVZ\&S, Raipur and KPZ, Bilaspur. The findings of our study are in accordance with the mean calcium level of $11.21 \pm 0.35 \mathrm{mg} / 100 \mathrm{gm}$ in meat samples reported by Siham et al. (2013) ${ }^{[16]}$ and $11 \mathrm{mg} / 100 \mathrm{gm}$ by Casey (1992) ${ }^{[3]}$.

The mean phsophorus content in meat samples of $\mathrm{MBZ}$, Bhilai was significantly $(\mathrm{p}<0.05)$ lower in summer and premonsoon season as compared to NVZ\&S, Raipur and KPZ, Bilaspur. The mean phosphorus level in meat samples 
recorded by Siham et al. (2013) [16] was $154.5 \pm 3.82 \mathrm{mg} /$ $100 \mathrm{gm}$ while Casey (1992) ${ }^{[3]}$ reported phosphorus content of meat samples to be $155.5 \mathrm{mg}$ per $100 \mathrm{gm}$ which is in accordance with the findings of our study.

The magnesium content in meat samples of MBZ, Bhilai was significantly $(\mathrm{p}<0.05)$ lower in summer and pre-monsoon season as compared to NVZ\&S, Raipur and KPZ, Bilaspur. The findings of our study are in agreement with the findings of Siham et al. (2013) [16] who have reported mean phosphorus level in meat samples to be $27.31 \pm 4.57$ mg/100gm. Similarly, Casey (1992) ${ }^{[3]}$ has also reported mean phosphorus level of meat samples to be $19.7 \mathrm{mg} / 100 \mathrm{gm}$ which is in congruity with our findings.

The level of copper in meat samples of MBZ, Bhilai was significantly $(\mathrm{p}<0.05)$ lower in summer and pre-monsoon season as compared to NVZ\&S, Raipur and KPZ, Bilaspur. The mean copper level in meat samples recorded by Casey (1992) ${ }^{[3]}$ was $0.30 \mathrm{mg}$ per $100 \mathrm{gm}$ which is similar to the findings of our study.

The mean iron content in meat samples of MBZ, Bhilai was significantly $(\mathrm{p}<0.05)$ lower in summer and pre-monsoon season as compared to NVZ\&S, Raipur and KPZ, Bilaspur. The mean iron level in meat samples of our study are in close proximity to those stated by Siham et al. (2013) ${ }^{[16]}$ as $3.50 \pm$ $0.45 \mathrm{mg} / 100 \mathrm{gm}$ as well as Casey (1992) ${ }^{[3]}$ who has reported
$4.37 \mathrm{mg} / 100 \mathrm{gm}$ level of iron in meat samples.

The level of zinc in meat samples of MBZ, Bhilai was significantly $(\mathrm{p}<0.05)$ lower in summer season as compared to NVZ\&S, Raipur. However, the mean zinc content of meat samples of MBZ, Bhilai was significantly $(\mathrm{p}<0.05)$ lower in summer and pre-monsoon season as compared to KPZ, Bilaspur. The mean zinc level in meat samples recorded by Casey (1992) ${ }^{[3]}$ was $3.51 \mathrm{mg}$ per $100 \mathrm{gm}$ which is similar to our observations.

The macro and micro mineral content of soil, water and meat samples of 03 selected zoos during this study was recorded to be comparatively lower than the normal recommended values. The decreased content of these minerals could have led to increased prevalence of gastrointestinal parasites in captive wild carnivores under study (Mishra, 2017) ${ }^{[12]}$.

It has been assumed that minerals play an important role in affecting susceptibility of animals to parasitic load and exert direct anthelmintic affect by influencing host metabolism and modulating immunity of the animal. Additionally, gastrointestinal parasites have been proposed to alter the utilization of calcium, phosphorus and magnesium in affected animals. Immunocompromised status arising due to deficiency of macro and micro minerals also leads to prolonged nematode survival (Fekete and Kellems, 2007) ${ }^{[7]}$.

Table 1: Mean \pm S.E.values of micro and macro mineral level in soil samples of different zoos

\begin{tabular}{|c|c|c|c|c|}
\hline \multirow{2}{*}{ Mineral } & \multirow{2}{*}{ Season } & MBZ $(\mathbf{n}=\mathbf{6})$ & NVZ $(\mathbf{n}=\mathbf{6})$ & KPZ $(\mathbf{n}=\mathbf{6})$ \\
\cline { 3 - 5 } & & Mean \pm S.E. & Mean \pm S.E. & Mean \pm S.E. \\
\hline \multirow{2}{*}{$\mathrm{Ca}$} & Summer & $1094.93 \pm 1.39^{\mathrm{b}}$ & $1128.43 \pm 1.90^{\mathrm{a}}$ & $1129.76 \pm 2.10^{\mathrm{a}}$ \\
\cline { 2 - 5 } & Pre-monsoon & $1089.6 \pm 2.16^{\mathrm{b}}$ & $1128.15 \pm 0.60^{\mathrm{a}}$ & $1126.48 \pm 1.02^{\mathrm{a}}$ \\
\hline \multirow{2}{*}{$\mathrm{P}$} & Summer & $0.06 \pm 0.00^{\mathrm{b}}$ & $0.08 \pm 0.00^{\mathrm{a}}$ & $0.08 \pm 0.00^{\mathrm{a}}$ \\
\cline { 2 - 5 } & Pre-monsoon & $0.06 \pm 0.00^{\mathrm{b}}$ & $0.08 \pm 0.00^{\mathrm{a}}$ & $0.08 \pm 0.00^{\mathrm{a}}$ \\
\hline \multirow{2}{*}{$\mathrm{Mg}$} & Summer & $226.75 \pm 3.81^{\mathrm{b}}$ & $246.10 \pm 3.06^{\mathrm{a}}$ & $247.52 \pm 3.45^{\mathrm{a}}$ \\
\cline { 2 - 5 } & Pre-monsoon & $213.78 \pm 2.08^{\mathrm{b}}$ & $240.83 \pm 1.22^{\mathrm{a}}$ & $244.03 \pm 3.68^{\mathrm{a}}$ \\
\hline \multirow{2}{*}{$\mathrm{Cu}$} & Summer & $1.12 \pm 0.01^{\mathrm{b}}$ & $1.37 \pm 0.01^{\mathrm{a}}$ & $1.35 \pm 0.01 \mathrm{a}$ \\
\cline { 2 - 5 } & Pre-monsoon & $1.12 \pm 0.01^{\mathrm{b}}$ & $1.36 \pm 0.02^{\mathrm{a}}$ & $1.36 \pm 0.01^{\mathrm{a}}$ \\
\hline \multirow{2}{*}{$\mathrm{Fe}$} & Summer & $30.43 \pm 0.08^{\mathrm{c}}$ & $39.26 \pm 0.37^{\mathrm{b}}$ & $41.54 \pm 0.42^{\mathrm{a}}$ \\
\cline { 2 - 5 } & Pre-monsoon & $30.44 \pm 0.08^{\mathrm{c}}$ & $36.73 \pm 0.86^{\mathrm{b}}$ & $39.26 \pm 0.37^{\mathrm{a}}$ \\
\hline \multirow{2}{*}{$\mathrm{Zn}$} & Summer & $1.12 \pm 0.01^{\mathrm{b}}$ & $1.39 \pm 0.36^{\mathrm{a}}$ & $1.43 \pm 0.02^{\mathrm{a}}$ \\
\cline { 2 - 5 } & Pre-monsoon & $1.03 \pm 0.00^{\mathrm{b}}$ & $1.35 \pm 0.01^{\mathrm{a}}$ & $1.37 \pm 0.01^{\mathrm{a}}$ \\
\hline \multirow{2}{*}{$\mathrm{Se}$} & Summer & $0.00 \pm 0.00$ & $0.00 \pm 0.00$ & $0.01 \pm 0.00$ \\
\cline { 2 - 5 } & Pre-monsoon & $0.00 \pm 0.00$ & $0.00 \pm 0.00$ & $0.00 \pm 0.00$ \\
\hline
\end{tabular}

$\mathrm{a}, \mathrm{b}$ and $\mathrm{c}=$ Means within the same row with different superscripts differ significantly $(\mathrm{p}<0.05)$

Table 2: Mean \pm S.E.values of micro and macro mineral level in water samples of different zoos

\begin{tabular}{|c|c|c|c|c|}
\hline \multirow{2}{*}{ Mineral } & \multirow{2}{*}{ Season } & MBZ $(\mathbf{n}=\mathbf{6})$ & NVZ $(\mathbf{n}=6)$ & KPZ $(\mathbf{n}=\mathbf{6})$ \\
\cline { 2 - 5 } & & Mean \pm S.E. & Mean \pm S.E. & Mean \pm S.E. \\
\hline \multirow{2}{*}{$\mathrm{Ca}$} & Summer & $37.05 \pm 0.74^{\mathrm{b}}$ & $42.67 \pm 0.09^{\mathrm{a}}$ & $43.66 \pm 0.49^{\mathrm{a}}$ \\
\cline { 2 - 5 } & Pre-monsoon & $34.46 \pm 0.39^{\mathrm{b}}$ & $40.67 \pm 0.24^{\mathrm{a}}$ & $40.28 \pm 0.29^{\mathrm{a}}$ \\
\hline \multirow{2}{*}{$\mathrm{P}$} & Summer & $0.10 \pm 0.00^{\mathrm{b}}$ & $0.10 \pm 0.00^{\mathrm{a}}$ & $0.10 \pm 0.00^{\mathrm{a}}$ \\
\cline { 2 - 5 } & Pre-monsoon & $0.08 \pm 0.00^{\mathrm{b}}$ & $0.10 \pm 0.00^{\mathrm{a}}$ & $0.10 \pm 0.00^{\mathrm{a}}$ \\
\hline \multirow{2}{*}{$\mathrm{Mg}$} & Summer & $1.51 \pm 0.01^{\mathrm{b}}$ & $1.54 \pm 0.01^{\mathrm{ab}}$ & $1.56 \pm 0.01^{\mathrm{a}}$ \\
\cline { 2 - 5 } & Pre-monsoon & $1.23 \pm 0.22$ & $1.46 \pm 0.01$ & $1.50 \pm 0.02$ \\
\hline \multirow{2}{*}{$\mathrm{Cu}$} & Summer & $0.18 \pm 0.04^{\mathrm{b}}$ & $0.30 \pm 0.03^{\mathrm{a}}$ & $0.28 \pm 0.03^{\mathrm{a}}$ \\
\cline { 2 - 5 } & Pre-monsoon & $0.15 \pm 0.03$ & $0.23 \pm 0.04$ & $0.23 \pm 0.04$ \\
\hline \multirow{2}{*}{$\mathrm{Fe}$} & Summer & $1.56 \pm 0.01$ & $1.56 \pm 0.01$ & $1.57 \pm 0.01$ \\
\cline { 2 - 5 } & Pre-monsoon & $1.50 \pm 0.01$ & $1.48 \pm 0.01$ & $1.48 \pm 0.01$ \\
\hline \multirow{2}{*}{$\mathrm{Zn}$} & Summer & $1.38 \pm 0.05^{\mathrm{b}}$ & $3.11 \pm 0.20^{\mathrm{a}}$ & $3.13 \pm 0.22^{\mathrm{a}}$ \\
\cline { 2 - 5 } & Pre-monsoon & $1.07 \pm 0.01^{\mathrm{c}}$ & $2.53 \pm 0.04^{\mathrm{a}}$ & $1.38 \pm 0.05^{\mathrm{b}}$ \\
\hline \multirow{2}{*}{$\mathrm{Se}$} & Summer & $0.01 \pm 0.00$ & $0.01 \pm 0.00$ & $0.01 \pm 0.00$ \\
\cline { 2 - 5 } & Pre-monsoon & $0.01 \pm 0.00$ & $0.01 \pm 0.00$ & $0.01 \pm 0.00$ \\
\hline
\end{tabular}

$\mathrm{a}, \mathrm{b}$ and $\mathrm{c}=$ Means within the same row with different superscripts differ significantly $(\mathrm{p}<0.05)$ 
Table 3: Mean \pm S.E.values of micro and macro mineral level in meat samples of different zoos

\begin{tabular}{|c|c|c|c|c|}
\hline \multirow{2}{*}{ Mineral } & \multirow{2}{*}{ Season } & MBZ $(\mathbf{n}=\mathbf{6})$ & NVZ $(\mathbf{n}=\mathbf{6})$ & KPZ $(\mathbf{n}=\mathbf{6})$ \\
\cline { 3 - 5 } & & Mean \pm S.E. & Mean \pm S.E. & Mean \pm S.E. \\
\hline \multirow{2}{*}{$\mathrm{Ca}$} & Summer & $80.17 \pm 1.01^{\mathrm{c}}$ & $110 \pm 0.58^{\mathrm{a}}$ & $106.17 \pm 0.87^{\mathrm{b}}$ \\
\cline { 2 - 5 } & Pre-monsoon & $82.83 \pm 0.95^{\mathrm{b}}$ & $105.5 \pm 1.45^{\mathrm{a}}$ & $104.67 \pm 0.80^{\mathrm{a}}$ \\
\hline \multirow{2}{*}{$\mathrm{P}$} & Summer & $1174.17 \pm 14.88^{\mathrm{b}}$ & $1487.5 \pm 15.83^{\mathrm{a}}$ & $1477.33 \pm 10.86^{\mathrm{a}}$ \\
\cline { 2 - 5 } & Pre-monsoon & $1153 \pm 12.23^{\mathrm{b}}$ & $1473.67 \pm 10.55^{\mathrm{a}}$ & $1471.33 \pm 9.32^{\mathrm{a}}$ \\
\hline \multirow{2}{*}{$\mathrm{Mg}$} & Summer & $154.33 \pm 1.20^{\mathrm{b}}$ & $186.5 \pm 2.43^{\mathrm{a}}$ & $185.33 \pm 1.76^{\mathrm{a}}$ \\
\cline { 2 - 5 } & Pre-monsoon & $155.83 \pm 1.74^{\mathrm{c}}$ & $188.83 \pm 1.54^{\mathrm{a}}$ & $184.17 \pm 1.19^{\mathrm{b}}$ \\
\hline \multirow{2}{*}{$\mathrm{Cu}$} & Summer & $1.58 \pm 0.10^{\mathrm{b}}$ & $2.8 \pm 0.06^{\mathrm{a}}$ & $2.63 \pm 0.08^{\mathrm{a}}$ \\
\cline { 2 - 5 } & Pre-monsoon & $1.65 \pm 0.07^{\mathrm{b}}$ & $2.7 \pm 0.1^{\mathrm{a}}$ & $2.63 \pm 0.16^{\mathrm{a}}$ \\
\hline \multirow{2}{*}{$\mathrm{Fe}$} & Summer & $34.13 \pm 1.73^{\mathrm{b}}$ & $42.91 \pm 0.30^{\mathrm{a}}$ & $42.63 \pm 0.09^{\mathrm{a}}$ \\
\cline { 2 - 5 } & Pre-monsoon & $32.28 \pm 1.10^{\mathrm{b}}$ & $42.6 \pm 0.19^{\mathrm{a}}$ & $42.68 \pm 0.15^{\mathrm{a}}$ \\
\hline \multirow{2}{*}{$\mathrm{Zn}$} & Summer & $29.03 \pm 0.56^{\mathrm{c}}$ & $34.57 \pm 0.28^{\mathrm{a}}$ & $33 \pm 0.17^{\mathrm{b}}$ \\
\cline { 2 - 5 } & Pre-monsoon & $31.87 \pm 0.79^{\mathrm{b}}$ & $34.7 \pm 0.13^{\mathrm{a}}$ & $34.3 \pm 0.34^{\mathrm{a}}$ \\
\hline \multirow{2}{*}{$\mathrm{Se}$} & Summer & $1061.17 \pm 10.64^{\mathrm{b}}$ & $1175.83 \pm 17.21^{\mathrm{a}}$ & $1201.17 \pm 12.58^{\mathrm{a}}$ \\
\cline { 2 - 5 } & Pre-monsoon & $1034.5 \pm 11.25^{\mathrm{b}}$ & $1232.67 \pm 19.87^{\mathrm{a}}$ & $1225.83 \pm 21.43^{\mathrm{a}}$ \\
\hline
\end{tabular}

$\mathrm{a}, \mathrm{b}$ and $\mathrm{c}=$ Means within the same row with different superscripts differ significantly $(\mathrm{p}<0.05)$

\section{Conclusion}

The macro and micro mineral level in soil, water and meat samples were found to be lower in all 03 zoos which could have resulted in higher incidence of gastrointestinal parasites in captive wild carnivores of 03 zoos.

\section{Acknowledgement}

Authors are thankful to Principal Chief Conservator of Forest (Wildlife), Chhattisgarh, for granting permission to undertake this work. Authors are also thankful to Veterinary Assistant Surgeon Maitri Bagh Zoo, Bhilai, Nandanvan Zoo and Safari, Raipur and Kanan Pendari Zoo, Bilaspur and Dean, Veterinary College, Anjora, DSVCKV, Durg for providing necessary facilities for this research work.

\section{References}

1. APHA. Standard methods for the examination of water and waste water. Edn 14, American Public Health Association, Washington, D.C, 1998, 242-246.

2. Barmon BC, Begum N, Labony SS, Kundu UK, Dey A R, Dey TR. Study of gastro-intestinal parasites of deer at Char Kukri Mukri in Bhola District, Bangladesh Journal of Veterinary Medicine 2014;2(1):27-33.

3. Casey NH. Goat Meat in Human Nutrition. $V^{\text {th }}$ International Conference on Goats, Pretoria, South Africa, 1992, 587-588.

4. Chakraborty A, Gogoi AR, Choudhary B. Prevalence of parasitic infection in captive wild herbivores in a zoo in Assam, India. Indian Journal of Animal Science 1994;9:149-152.

5. Chandrakar S, Khutey JK, Roy S, Singh J, Mishra B, Jambagi K et al. Prevalence of gastrointestinal nematodes in captive wild carnivores of Chhattisgarh, India. International Journal of Current Microbiology and Applied Sciences 2020;9(3):609-615.

6. Davis J. Mineral profile of livestock farm waste and its bio-accumulation effects in crossbred cattle Ph.D. thesis submitted to Kerala Veterinary and Animal Sciences University, 2017.

7. Fekete SG, Kellems RO. Interrelationship of feeding with immunity and parasitic infection: A review. Veterinarni Medicina. 2007;52(4):131-143

8. Joshi BP. Wild animal medicine. Oxford and IBH Publishing, New Delhi, 1991, 97.

9. Khutey JK, Chandrakar S, Roy S, Singh J, Mishra B, Jambagi K et al. Studies on prevalence of gastro- intestinal parasites in captive wild herbivores in Nandanvan Zoo, Raipur. Journal of Entomology and Zoology Studies 2020;8(2):645-648.

10. Maske DK, Bhilegaonkar NC, Sardey MR. Helminth parasites in zoo animals of Maharajbagh, Nagpur, Maharashtra State. Indian Journal of Animal Science 1990;5:277-278.

11. McDowell LR, Conard JH, Ellis GL, Loosli JK. Mineral deficiencies and imbalance and their diagnosis. In: Nutrition in subtropics and tropics. Gilchrist FMC, Mackei RI (Eds.). Pretoria, South Africa, 1984, 67-68.

12. Mishra B. Studies on health status of Crocodylus palustris at Crocodile Conservation Park, Kotmi-Sonar (Chhattisgarh). M.V.Sc. Thesis submitted to Chhattisgarh Kamdhenu Vishwavidyalaya, Durg, Chhattisgarh. 2017.

13. Piper CS. Soil and Plant Analysis. Hassell Press, Adelaide, Australia, 1942, 42-43.

14. Sahoo N, Roy PK, Das A, Samantaray RK, Dehuri M, Bharti KMN. Gastrointestinal helminthic infection in animals of Nandankanan Zoological Park. Journal of Veterinary Parasitology 2009;23(1):95-96.

15. Siddiqi Z, Gillani A, Ahsun-ul-Haq, Habar E. Study on the chemical composition of breast and thigh muscle tissues in different breeds of poultry. Pakistan Journal of Agriculture Science 1994;31(4):322-323.

16. Siham Abdelwhab A, Daoud Alzubair A. A study in minerals concentrations in Red Meat. International Journal of Science and Research 2013;4(8):708-709.

17. Singh C, Bajpai RK, Tiwari A, Chandra M, Krishna B. Evaluations of soil fertility status of available major nutrients $(\mathrm{N}, \mathrm{P} \& \mathrm{~K})$ and micro nutrients $(\mathrm{Fe}, \mathrm{Mn}, \mathrm{Cu} \&$ $\mathrm{Zn}$ ) in Vertisol of Balodabazar block in Balodabazar district of Chhattisgarh. Journal of Pharmacognosy and Phytochemistry 2018;SP2:10-12.

18. Skerman KD, Hillard JJ. A handbook for studies of helminth parasite of ruminant. Near East Animal Health Institute, Iran, FAO, Rome, 1966, 67-68.

19. Soulsby E JL. Helminths, Arthropods and Protozoa of domesticated animals. Edn7, Blackwell Scientific Publications, London, 112-134.

20. Thawait VK, Maiti SK, Dixit AA. Prevalence of gastrointestinal parasites in captive wild animals of Nandan Van Zoo, Raipur, Chhattisgarh. Veterinary World 2014;7(7):448-451.

21. Thiangtum K, Nimsuphun B, Pinyopanuwat N, Chimnoi W, Tunwattana W, Tongthainan D et al. Seroprevalence 
of Toxoplasma gondi in captive felids in Thailand. Veterinary Parasitology 2006;136:351-355.

22. VanWyk IC, Boomker J. The prevalence of helminthes in some common antelopes, warthogs and a bushpig in the Limpopo province, South Africa. Parasites of South African Wildlife. XIX, Ondersteport Journal of Veterinary Research 2011;78:1-11.

23. Varadharajan A, Kandasamy A. A survey of gastrointestinal parasites of wild animals in captivity in the V. O. C Park and Mini zoo, Coimbatore. Zoo's Print Journal 2000;15:257-258.

24. WHO. Guidelines for drinking water quality. World Health Organization, Geneva, 2002, 240-259. 